\title{
Hubungan antara komunikasi interpersonal orangtua-remaja dengan keterampilan sosial remaja
}

\author{
Kinanti Larasati dan Adijanti Marheni \\ Program Studi Sarjana Psikologi, Fakultas Kedokteran, Universitas Udayana \\ adijantimarheni@gmail.com
}

\begin{abstract}
Abstrak
Remaja adalah salah satu masa perkembangan yang dimulai dari usia 13 tahun sampai 21 tahun. Pada masa ini kebanyakan waktu dihabiskan remaja dalam kegiatan sekolah atau bersama teman sebaya. Interaksi dan penerimaan teman sebaya merupakan hal penting bagi perkembangan remaja. Untuk dapat berinteraksi dan diterima dengan baik oleh lingkungan, remaja diharapkan dapat memiliki keterampilan sosial yang baik. Keterampilan sosial terutama diperoleh melalui proses pembelajaran (terutama pembelajaran sosial, termasuk observasi, modeling, latihan, dan proses umpan balik). Salah satu faktor yang memengaruhi keterampilan sosial seseorang adalah keluarga. Komunikasi orangtua dengan anak merupakan proses pembentukan sikap dan perilaku anak, yang berpengaruh pada perkembangan anak dan disinilah unsur pendidikan terhadap anak akan dibentuk. Remaja akan belajar cara berinteraksi dan berperilaku yang baik melalui interaksi mereka dengan orangtua. Penelitian ini bertujuan untuk mengetahui hubungan antara komunikasi interpersonal orangtua-remaja dengan keterampilan sosial remaja. Subjek pada penelitian ini adalah 114 orang siswa SMA Dwijendra Denpasar. Instrument dalam penelitian ini adalah skala komunikasi interpersonal orangtua-remaja dan skala keterampilan sosial remaja. Hasil analisis korelasi product moment menunjukkan angka korelasi sebesar 0,681 dan taraf signifikansi sebesar 0,000 $(\mathrm{p}<0,05)$, yang berarti ada hubungan yang signifikan antara komunikasi interpersonal orangtua-remaja dengan keterampilan sosial remaja. Semakin efektif komunikasi interpersonal yang dimiliki orangtua-remaja maka akan semakin tinggi keterampilan sosial yang dimiliki remaja, begitu pula sebaliknya semakin kurang efektif komunikasi interpersonal orangtua-remaja maka akan semakin rendah keterampilan sosial yang dimiliki remaja.
\end{abstract}

Kata kunci: Remaja, komunikasi interpersonal antara orangtua-remaja, keterampilan sosial.

\begin{abstract}
Adolescence is one of developmental periods that start from the age of 13 to 21 . At this period, adolescent spent most of their times in school activities or with peers. Peer interaction and acceptance are important for adolescent development. To be able to interact and be well received by the environment, teenagers are expected to have good social skills. Social skills are primarily gained through the learning process (especially social learning, including observation, modeling, practice, and feedback process). One of the factors that affect a person's social skills is family. Communication between parent-adolescent is the process of forming the attitude and behavior of children, which affects the development of children and this is where the element of education of children will be formed. Adolescent will learn how to interact and behave well through their interactions with parents. This study aims to determine the correlation between parent-adolescent interpersonal communication with adolescent social skills. The subjects in this study were 114 students of Dwijendra High School Denpasar. The instruments in this research are parent-adolescent interpersonal communication scale and adolescent social skill scale. The result of product moment correlation analysis shows the correlation number of 0.681 and significancy level of $0.000(\mathrm{p}<0,05)$, which mean there is a significant correlation between parent-adolescent interpersonal communication with adolescent social skill. The more effective the parent-adolescent interpersonal communication the higher the adolescent social skills, and the less effective the parentadolescent interpersonal communication the lower the adolescent social skills.
\end{abstract}

Keywords: Adolescence, parent-adolescent interpersonal communication, social skills. 


\section{LATAR BELAKANG}

Masa remaja merupakan masa peralihan atau transisi dari masa anak-anak ke masa dewasa. Papalia (2009) menyatakan masa remaja merupakan masa transisi yang meliputi perkembangan fisik, kognitif, emosi, dan perubahan sosial, yang dimulai dari usia 11 tahun hingga 19 atau 20 tahun. Menurut Hurlock (2004) istilah remaja atau adolescence berasal dari kata latin yang berarti tumbuh menjadi dewasa, yang memiliki arti lebih luas mencakup kematangan mental, emosional, sosial dan fisik. Rice dan Dolgin (2002) menyatakan remaja sebagai jembatan antara masa anak-anak dengan masa dewasa yang harus dilewati individu sebelum mereka mengambil posisi sebagai orang dewasa yang matang, bertanggung jawab, dan kreatif.

Erikson (dalam Papalia, 2009) mengatakan tugas utama yang akan dihadapi seseorang pada masa remaja adalah krisis pencarian identitas melawan kebingungan identitas. Masa remaja yang merupakan masa peralihan mendorong remaja untuk berusaha mencari identitas diri mereka dari berbagai kegiatan di lingkungan sekitar. Dalam usaha remaja mencoba berbagai peran di lingkungan membuat remaja rentan untuk terjerumus ke dalam tindakan yang kurang baik. Dimulai dari tindakan melanggar aturan di sekolah sampai dengan tindakan pelanggaran hukum atau tindakan pidana.

Kenakalan remaja (juvenile delinquency) merupakan gejala sakit (patologis) secara sosial pada anak-anak dan remaja yang disebabkan oleh satu bentuk pengabaian sosial, sehingga terbentuk tingkah laku yang menyimpang (Kartono, Kartini, 2013). Berdasarkan hasil wawancara dengan seorang guru SMA, permasalahan yang seringkali muncul adalah pelanggaran pada aturan-aturan sekolah seperti berpakaian yang tidak sesuai, keterlambatan hadir, dan membawa benda yang tidak diperbolehkan seperti telepon gengam.

Kartono, Kartini (2013) menyatakan delinkuensi atau kejahatan remaja merupakan reaksi terhadap masalah psikis remaja itu sendiri, kurang lebih $90 \%$ dari jumlah remaja delinkuen berasal dari keluarga berantakan (broken home). Kondisi keluarga yang tidak bahagia akan menimbulkan masalah psikologis dan penyesuaian diri pada remaja.

Remaja sebagai makhluk sosial tentunya tidak terlepas dari hubungan dengan orang lain yang dapat diperoleh melalui kelompok sosial. Rice dan Dolgin (2002) mengemukakan kelompok sosial remaja terdiri dari kelompok sosial formal dan informal. Kelompok sosial formal meliputi remaja yang mengikuti pendidikan sekolah, sedangkan kelompok informal melipui remaja yang tidak bersekolah yang berkumpul bersama membentuk kelompok sosial.

Menurut Rice dan Dolgin (2002), di dalam kelompok sosial formal, remaja yang mengikuti pendidikan sekolah akan berpartisipasi dalam kegiatan formal yaitu subsistem akademis, kegiatan semiformal yaitu subsistem aktivitas, dan juga subsistem pertemanan. Terdapat remaja yang lebih memilih aktif dalam kegiatan formal di sekolah, remaja yang lebih memperhatikan pengetahuan dan prestasi. Selain itu terdapat pula remaja yang lebih tertarik mengikuti kegiatan semiformal dengan mengikuti berbagai kegiatan ekstrakurikuler yang tersedia di sekolah. Kegiatan dalam subsistem pertemanan akan terlihat dari remaja yang membentuk kelompok-kelompok kecil di sekolah, yang biasanya memiliki kesamaan minat.

Sekolah tidak hanya memberikan fasilitas pendidikan akademis, tetapi juga memberikan kesempatan pada remaja untuk berinteraksi dengan teman sebaya juga membentuk kelompok-kelompok sosial (Rice \& Dolgin, 2002). Tidak semua remaja memilih untuk mengikuti berbagai kegiatan yang difasilitasi sekolah, terdapat remaja yang memilih hanya mengikuti kegiatan belajar yang memang wajib diikuti. Dari wawancara dengan seorang guru SMA, didapat bahwa memang ada kelompok remaja yang senang mengikuti banyak kegiatan di sekolah, biasanya kelompok remaja tersebut memang suka berkumpul dengan teman-teman dan tidak kesulitan untuk bergaul. Ada remaja yang memang kurang aktif di kegiatan di luar pelajaran, tetapi bukan berarti tidak memiliki teman atau sulit bergaul, hal ini lebih kepada kepribadian yang mungkin pemalu atau kurang suka di keramaian.

Berdasarkan hasil studi Davis dan Forsythe (dalam Mu'tadin, 2006), terdapat 8 faktor yang memengaruhi keterampilan sosial seseorang yaitu keluarga, lingkungan, kepribadian, rekreasi, pergaulan dengan lawan jenis, pendidikan atau sekolah, persahabatan dan solidaritas kelompok, serta lapangan kerja. Keaktifan remaja tidak hanya di luar pelajaran, tetapi dapat dilihat juga dalam kegiatan belajar-mengajar. Di dalam proses belajar ada remaja yang secara aktif bertanya mengenai hal yang tidak dimengerti dan menjawab ketika guru memberi pertanyaan, tetapi ada juga remaja yang lebih memilih diam dan mendengarkan, serta enggan untuk bertanya ketika kurang memahami sesuatu. Ketakutan remaja untuk bertanya ke guru dan memilih diam tentu saja menghambat dalam mencapai nilai akademik yang maksimal.

Pada masa remaja awal, remaja lebih banyak menghabiskan waktu bersama teman sebaya dibandingkan dengan orangtua, dan biasanya remaja akan membentuk cliques, yaitu kelompok yang biasanya terdiri dari empat sampai delapan orang dengan jenis kelamin yang sama, yang memiliki kesamaan nilai dan minat (Shaffer, 2002). Dalam hal ini adapula remaja yang lebih memilih untuk menyendiri atau berteman dengan beberapa orang saja, tanpa ikut serta dalam kelompokkelompok yang ada di sekolahnya.

Dalam menjalani kehidupan di sekolah, remaja harus dapat menyesuaikan diri dengan lingkungan sekitarnya. Hal ini terlihat dalam kenyataan melalui hasil wawancara dengan salah seorang guru SMA, dimana terdapat beberapa remaja yang memang terlihat sering sendirian, terutama saat masih duduk di bangku kelas sepuluh, karena pada saat itu remaja sebagai siswa baru di sekolah akan menyesuaikan diri dengan lingkungan sekolah dan teman-teman baru. Remaja membutuhkan waktu untuk membangun hubungan pertemanan di sekolah baru, apalagi untuk remaja yang merantau atau tidak terdapat teman yang berasal dari SMP yang sama. Untuk dapat menyesuaikan diri dan diterima oleh lingkungan atau teman sebaya, remaja harus mampu 
berperilaku sesuai dengan nilai dan apa yang diharapkan oleh orang-orang sekitarnya.

Shaffer (2002) menyatakan penerimaan dari lingkungan atau teman sebaya dipengaruhi oleh beberapa faktor, memiliki temperamen yang menyenangkan dan kemampuan akademik yang baik akan membantu penerimaan lingkungan, tetapi lebih penting lagi untuk menunjukkan kemampuan sosial-kognitif yang baik dan berperilaku yang berkompeten secara sosial. Meyers dan Nelson (dalam Rice \& Dolgin, 2002) menyatakan kualitas personal dan keterampilan sosial (social skill) merupakan kriteria penting untuk popularitas dan telah terbukti sangat penting dalam mendapatkan penerimaan sosial.

Mu'tadin (2006) mengemukakan bahwa salah satu tugas perkembangan remaja dalam fase perkembangan masa remaja madya dan remaja akhir adalah memiliki keterampilan sosial (social skill) untuk dapat menyesuaikan diri dengan kehidupan sehari-hari. Keterampilan sosial ini akan membantu remaja dalam memahami lingkungan dan memunculkan perilaku yang dapat diterima dan diharapkan oleh lingkungannya. Keterampilan sosial menurut Comb dan Slaby (dalam Gimpel \& Merrel, 1998), merupakan kemampuan untuk berinteraksi dengan orang lain dalam suatu konteks sosial yang ada, dengan suatu cara yang spesifik, yang secara sosial dapat diterima atau bernilai dan secara bersamaan menguntungkan pribadi, saling menguntungkan untuk diri maupun orang lain, atau menguntungkan terutama untuk orang lain.

Remaja mendapat proses pembelajaran melalui lingkungan keluarga maupun sekolah, dimana pada setiap lingkungan remaja akan memiliki sosok yang dijadikan contoh. Di dalam lingkungan keluarga sosok yang dapat dijadikan contoh adalah orangtua atau saudara, sedangkan di lingkungan sekolah remaja bisa belajar dari guru maupun teman sebaya. Hasil studi Davis dan Forsythe (dalam Mu'tadin, 2006) salah satu aspek yang memengaruhi keterampilan sosial dalam kehidupan remaja adalah keluarga.

Keluarga adalah kelompok sosial yang paling mendasar dalam masyarakat, yang biasanya terdiri dari satu atau dua orangtua dan anak-anak (Olson \& Defrain, 2003). Keluarga merupakan kelompok utama dalam proses pembelajaran seseorang, karena keluarga merupakan kelompok sosial pertama dimana seseorang mulai belajar memahami banyak hal. Bagaimana remaja berinteraksi dan berperilaku di dalam lingkungan keluarga akan terlihat juga ketika berinteraksi dan berperilaku di lingkungan lainnya, misalnya di sekolah.

Offer dan Church (dalam Papalia, 2009) menyatakan pada usia remaja, waktu yang dimiliki lebih banyak dihabiskan dengan teman sebaya dibandingkan keluarga, akan tetapi, nilai dasar utama remaja tetap berasal pada orangtua. Hurlock (2004) mengemukakan remaja yang hubungan keluarganya kurang baik juga dapat mengembangkan hubungan yang buruk dengan orang-orang di luar rumah. Salah satu cara membangun hubungan yang baik di lingkungan keluarga adalah dengan membangun komunikasi yang baik pula antara anggota keluarga. Untuk dapat berinteraksi dalam situasi sosial apa pun yang dihadapi, remaja harus memiliki kemampuan berkomunikasi yang baik, kemampuan untuk berinteraksi dengan orang lain sesuai dengan standar sosial. Remaja yang dapat membangun komunikasi interpersonal dengan baik dan sesuai dengan orangtua akan memiliki kemampuan untuk berinteraksi dalam situasi apapun dan tetap dapat diterima secara sosial. Remaja, yang sedang dalam masa transisi memasuki masa dewasa, membutuhkan hubungan yang baik dengan kedua orangtua. Komunikasi menjadi sarana terpenting bagi orangtua dan remaja dalam membangun hubungan yang baik. Komunikasi interpersonal atau komunikasi antarpribadi merupakan suatu proses sosial, di mana adanya saling memengaruhi antar orang-orang yang terlibat di dalam proses sosial tersebut (Ramadhani, 2013).

Komunikasi orangtua dengan remaja merupakan proses pembentukan sikap dan perilaku remaja, yang berpengaruh pada perkembangan remaja dan disinilah unsur pendidikan terhadap remaja akan dibentuk (Gunawan, 2013). Melalui komunikasi orangtua juga dapat mengajarkan remaja cara berinteraksi yang baik dan sesuai dengan standar sosial masyarakat, seperti bagaimana cara menyampaikan gagasan, informasi, opini dengan baik, sehingga tidak menyinggung orang lain. Berdasarkan pemaparan di atas, peneliti merasa tertarik untuk mengetahui apakah hubungan yang baik antara orangtua dengan remaja yang tersalurkan melalui komunikasi interpersonal yang dibangun, memiliki hubungan dengan keterampilan sosial (social skill) yang dimiliki remaja.

\section{METODE PENELITIAN}

\section{Variabel dan Definisi Operasional}

Variabel bebas pada penelitian ini adalah komunikasi interpersonal antara orangtua dengan remaja. Variabel terikat pada penelitian ini adalah keterampilan sosial remaja. Adapun definisi operasional dari kedua variabel tersebut adalah sebagai berikut:

\section{Komunikasi Interpersonal Orangtua-Remaja}

Komunikasi interpersonal antara orangtua dengan remaja adalah suatu proses pengiriman pesan antara orangtua dengan remaja, dimana pesan yang disampaikan dapat berupa pikiran maupun perasaan, yang meliputi adanya saling memengaruhi antara keduanya. Komunikasi interpersonal antara orangtua dengan remaja pada penelitian ini diukur dengan skala komunikasi interpersonal orangtua-remaja yang disusun oleh peneliti berdasarkan aspek komunikasi interpersonal efektif oleh DeVito (1997).

Keterampilan Sosial

Keterampilan sosial adalah kemampuan individu untuk menyesuaikan diri dan berinteraksi dengan orang lain dalam suatu konteks sosial yang ada, melalui perilaku yang dapat diterima secara sosial. Keterampilan sosial dalam penelitian ini diukur dengan skala keteampilan sosial yang disusun oleh peneliti berdasarkan dimensi keterampilan sosial yang dikemukakan oleh Caldarella dan Merrell (dalam Gimpel \& Merrel, 1998).

\section{Responden}

Populasi dalam penelitian ini adalah siswa aktif yang bersekolah di SMA Dwijendra Denpasar. Sampel pada penelitian ini adalah sebagian dari siswa yang berada di kelas 
X dan XI, di SMA Dwijendra Denpasar. Karakteristik sampel dalam penelitian ini antara lain, tercatat sebagai remaja yang merupakan siswa aktif di SMA Dwijendra, tinggal dengan orangtua, Bersedia mengikuti seluruh proses pengambilan data. Alasan peneliti menggunakan siswa kelas X dan XI dikarenakan pada saat penelitian dilangsungkan siswa kelas XII sudah bukan merupakan siswa aktif karena sudah lulus Ujian Nasional dan tidak mengikuti kegiatan di sekolah lagi. Pada penelitian ini, pengambilan sampel dilakukan dengan menggunakan teknik probability sampling. Cara pengambilan sampel dilakukan dengan memilih secara random kelas-kelas yang telah terbagi pada setiap angkatan kelas $\mathrm{X}$ dan XI. Jumlah responden dalam penelitian ini adalah sebanyak 114 remaja.

\section{Lokasi Penelitian}

Proses pengambilan sampel dilakukan di SMA Dwijendra Denpasar. Penelitian dilaksanakan pada bulan Juni 2016.

\section{Alat Ukur}

Alat ukur yang digunakan pada penelitian ini adalah skala komunikasi interpersonal orangtua-remaja dan skala keterampilan sosial remaja. Skala komunikasi interpersonal orangtua-remaja yang digunakan dalam penelitian ini terdiri dari lima aspek untuk mengukur keefektifan komunikasi yang dibangun antara orangtua dengan remaja. Peneliti menyusun skala komunikasi interpersonal orangtua-remaja berdasarkan teori yang dikemukakan oleh DeVito (1997). Skala keterampilan sosial remaja yang digunakan dalam penelitian ini terdiri dari lima aspek untuk mengukur tingkat keterampilan sosial remaja. Peneliti menyusun skala keterampilan sosial remaja berdasarkan teori yang dikemukakan oleh Caldarella dan Merrell (dalam Gimpel \& Merrel, 1998). Skala komunikasi interpersonal orangtuaremaja terdiri dari 41 aitem, sedangkan skala keterampilan sosial remaja terdiri dari 58 aitem. Model skala yang digunakan pada kedua kuesioner ini adalah skala Likert dan aitem-aitem pada kuesioner terdiri dari aitem favorable serta aitem unfavorable. Pada pernyataan aitem favorable, setiap jawaban Sangat Tidak Setuju (STS) akan diberi nilai 1, Tidak Setuju (TS) akan diberi nilai 2, Setuju (S) akan diberi nilai 3, dan Sangat Setuju (SS) akan diberi nilai 4. Sedangkan dalam pernyataan aitem unfavorable, setiap jawaban Sangat Tidak Setuju (STS) akan diberi nilai 4, Tidak Setuju (TS) akan diberi nilai 3, Setuju (S) akan diberi nilai 2, dan Sangat Setuju (SS) akan diberi nilai 1 .

Hasil pengujian validitas skala komunikasi interpersonal orangtua-remaja menunjukkan nilai koefisien korelasi aitemtotal yang berkisar dari 0,306 sampai dengan 0,741. Hasil uji reliabilitas skala komunikasi interpersonal orangtua-remaja dengan menggunakan Cronbach Alpha $(\alpha)$ adalah sebesar 0,949 . Berdasarkan hasil pengujian maka skala komunikasi interpersonal orangtua-remaja dapat digunakan untuk mengukur efektifitas komunikasi interpersonal yang dibangun antara orangtua-remaja. Hasil pengujian validitas skala keterampilan sosial remaja menunjukkan nilai koefisien korelasi aitem-total yang berkisar dari 0,303 sampai dengan 0,792. Hasil uji reliabilitas skala keterampilan sosial remaja dengan menggunakan Cronbach Alpha $(\alpha)$ adalah sebesar
0,961. Berdasarkan hasil pengujian maka skala keterampilan sosial remaja dapat digunakan untuk mengukur tingkat keterampilan sosial yang dimiliki remaja.

\section{Metode Pengumpulan Data}

Pada penelitian ini, teknik yang digunakan peneliti untuk mengumpulkan informasi dari subjek adalah dengan menggunakan skala atau kuesioner. Skala yang digunakan pada penelitian ini adalah skala komunikasi interpersonal orangtua-remaja dan skala keterampilan sosial remaja. Setelah menentukan kelas secara acak untuk digunakan sebagai sampel, peneliti menyebarkan kuesioner yang kemudian diisi oleh responden. Jumlah kuesioner yang terisi lengkap dan akan dianalisis berjumlah 114 kuesioner.

\section{Teknik Analisis Data}

Teknik analisis yang digunakan untuk dapat menguji hipotesis dalam penelitian ini adalah analisis korelasi pearson product moment. Teknik analisis pearson product moment merupakan teknik statistik parametrik. Analisis ini digunakan untuk menguji hipotesis hubungan antara satu variabel bebas dengan satu variabel tergantung. Analisis dilakukan dengan menggunakan program SPSS 16.0 for Windows. Sebelum melakukan analisis data dengan pearson product moment, peneliti melakukan uji normalitas dan uji linearitas. Uji normalitas sebaran data dilakukan dengan menggunakan teknik Kolmogorov-Smirnov Goodness of Fit Test dan uji linearitas data dilakukan dengan tabel ANOVA (analysis of variance).

\section{HASIL PENELITIAN}

\section{Uji Asumsi}

Pada tabel 1 (terlampir) dapat dilihat variabel komunikasi interpersonal antara orangtua-remaja memiliki nilai Kolmogorov-Smirnov sebesar 0,578 dengan signifikasi sebesar 0,892 ( $>>0,05)$. Nilai tersebut menunjukkan bahwa data variabel komunikasi interpersonal antara orangtua-remaja berdistribusi normal. Pada tabel 1 juga dapat dilihat variabel keterampilan sosial nilai Kolmogorov-Smirnov sebesar 0,483 dengan signifikansi sebesar $0,974(\mathrm{p}>0,05)$. Nilai tersebut menunjukkan bahwa data variabel keterampilan sosial juga berdisitribusi normal.

Pada tabel 2 (terlampir) dapat dilihat bahwa nilai signifikansi linearity kedua variabel adalah 0,000. Nilai tersebut lebih kecil dari 0,05 sehingga dapat disimpulkan bahwa terdapat hubungan yang linear antara variabel komunikasi interpersonal orangtua-remaja dengan keterampilan sosial.

Berdasarkan hasil uji normalitas dan uji linearitas yang telah dilakukan, dapat disumpulkan bahwa data penelitian ini berdistribusi normal dan ada hubungan yang linear antara kedua variabel yang diteliti sehingga dapat dilanjutkan dengan menguji hipotesis penelitian. 


\section{Uji Hipotesis}

Pada penelitian ini, uji hipotesis dilakukan dengan analisis korelasi Pearson product moment. Berdasarkan hasil analisis korelasi Pearson product moment pada tabel 3 (terlampir), terdapat koefisien korelasi sebesar 0,681 dan signifikansi sebesar $0,000(\mathrm{p}<0,05)$. Hal tersebut menunujukkan bahwa komunikasi interpersonal memiliki korelasi yang signifikan terhadap keterampilan sosial.

\section{Analisis Data Tambahan}

Penelitian ini juga memberikan data tambahan dari hasil analisis data yang didapat. Hasil yang didapat dari data penelitian dapat dimasukkan ke dalam tiga kategori.

Pada tabel 4 (terlampir), kategorisasi komunikasi interpersonal antara orangtua dengan remaja menunjukkan hasil persentase komunikasi interpersonal yang efektif sebesar $100 \%$, sedangkan komunikasi interpersonal kurang efektif dan komunikasi interpersonal yang sangat efektif sebesar $0 \%$. Oleh karena itu dapat disimpulkan bahwa sebagian besar remaja SMA Dwijendra denpasar memiliki komunikasi interpersonal yang efektif dengan orangtua.

Pada tabel 5 (terlampir), kategorisasi keterampilan sosial menunjukkan hasil persentase keterampilan sosial yang sedang sebesar $100 \%$, sedangkan keterampilan sosial yang rendah dan keterampilan sosial yang tinggi sebesar $0 \%$. Oleh karena itu dapat disimpulkan bahwa sebagian besar remaja SMA Dwijendra denpasar memiliki keterampilan sosial yang sedang.

\section{PEMBAHASAN DAN KESIMPULAN}

Hasil analisis dari data yang telah terkumpul menunjukkan adanya hubungan yang signifikan antara komunikasi interpersonal antara orangtua-remaja dengan keterampilan sosial yaitu semakin efektif komunikasi interpersonal yang dibangun antara orangtua dengan remaja maka semakin tinggi keterampilan sosial yang dimiliki remaja.

Dari hasil analisis data, ditunjukkan bahwa sebagian besar remaja SMA Dwijendra Denpasar memiliki hubungan komunikasi interpersonal yang efektif dengan orangtua dan memiliki keterampilan sosial yang sedang. Artinya melalui komunikasi interpersonal dengan orangtua, remaja sudah dapat secara terbuka bercerita mengenai diri sendiri dan masalah yang dihadapi kepada orangtua. remaja juga dapat merasakan empati ketika orangtua mendengarkan saat berkomunikasi. Dari komunikasi interpersonal yang dibangun, remaja juga dapat merasakan dukungan, sikap positif atau respon positif, dan juga dapat berkomunikasi secara setara dengan orangtua.

Hasil analisis data menunjukkan remaja memiliki keterampilan sosial yang sedang, dimana remaja dapat membangun hubungan yang baik dengan teman sebaya, seperti memberi pujian atau nasehat, memberi bantuan dan mengajak berinteraksi. Remaja juga menunjukkan kontrol diri yang baik, dimana remaja mampu mengontrol emosi yang dimiliki, mampu mengikuti aturan dan menerima kritikan dari orang lain dengan baik. Remaja juga menunjukkan kemampuan akademis yang baik, dimana remaja mampu untuk memenuhi tugas-tugas yang diberikan secara mandiri dan mampu mengikuti arahan yang diberikan guru dengan baik. Selain itu remaja juga menunjukkan perilaku yang dapat mengikuti peraturan yang ada di lingkungannya, dapat menggunakan waktunya dengan baik dan mampu berbagi dengan orang lain. Remaja juga sudah mampu menunjukkan perilaku yang sesuai dan tepat dalam setiap situasi yang sedang dihadapi, dalam hal ini perilaku di lingkungan sekolah.

Hasil penelitian yang dilakukan Disiye dan Kodero (2015) menunjukkan remaja yang membangun komunikasi yang baik dan terbuka dengan orangtua akan dapat mempelajari keterampilan sosial dan perilaku dari orangtua, yang nantinya akan diterapkan dalam hubungan dengan teman sebaya. Usia remaja adalah saat bagi remaja untuk mengembangkan dunia sosial. Pada masa ini orangtua membentuk kesan penting bagi remaja yang akan mempengaruhi perilaku remaja di lingkungan sosial.

Rozali (2016) menyatakan dalam hasil penelitiannya bahwa pola asuh orangtua yang baik adalah pola asuh authoritative, dimana orangtua mengkomunikasikan segala sesuatu secara dua arah dengan remaja. Orangtua memberikan kesempatan pada remaja untuk menyampaikan hal-hal yang ada dalam pikirannya, sesuai dengan batas yang telah dibuat dan disepakati bersama. Orangtua menghargai pendapat dan minat remaja sehingga remaja akan merasa dihargai dan mandiri. Dengan membangun komunikasi interpersonal yang efektif, remaja akan dapat memiliki keterampilan sosial yang baik, dimana remaja akan dapat menghargai orang lain, menyesuaikan diri dan menempatkan diri di lingkungan sosial di luar keluarga.

Manajemen diri atau kontrol diri merupakan kemampuan untuk mengendalikan emosi yang dimiliki, mampu mengikuti aturan dan menerima kritikan dari orang lain dengan baik. Minarni (2017) dalam penelitiannya menyatakan berkomunikasi dengan remaja adalah salah satu hal yang paling penting yang dapat orangtua lakukan untuk menghindari persoalan emosi selama masa perkembangan remaja. Kontrol emosi menjadi salah satu aspek yang perlu dimiliki remaja untuk dapat memiliki keterampilan sosial yang baik.

Hasil penelitian yang dilakukan oleh Thakkar dan Sheth (2014) menunjukkan komunikasi yang dibangun antara orangtua dengan remaja memengaruhi kemampuan penyesuaian diri remaja dalam hal kepercayaan diri, prestasi dan kesejahteraan. Kemampuan menyesuaikan diri remaja yang merupakan salah satu aspek keterampilan sosial, sangat dipengaruhi oleh diskusi positif maupun negatif yang dilakukan dengan orangtua melalui komunikasi.

Leme, Del Prette, \& Coimbra (2015) mengemukakan dalam hasil penelitiannya bahwa remaja yang memiliki keterampilan sosial yang baik ditunjukkan dari interaksi atau komunikasi yang penuh kasih sayang, positif dan ada hubungan timbalbalik dengan orangtua. Memiliki keterampilan sosial membantu remaja untuk dapat memahami orang lain. 


\section{K. LARASATI \& A. MARHENI}

Selain komunikasi interpersonal antara orangtua-remaja, terdapat faktor lain yang dapat memengaruhi keterampilan sosial remaja, seperti interaksi remaja di lingkungan lain di luar keluarga, tipe kepribadian yang dimiliki remaja, hubungan remaja dengan teman sebaya, kegiatan yang diikuti remaja di sekolah, dan lain-lain. Seperti hasil studi yang dilakukan Davis dan Forsythe (dalam Mu'tadin, 2006), terdapat delapan faktor yang memengaruhi keterampilan sosial seseorang. Faktor-faktor tersebut antara lain yaitu keluarga, lingkungan, kepribadian, rekreasi, pergaulan dengan lawan jenis, pendidikan atau sekolah, persahabatan, dan lapangan kerja.

Peneliti melihat adanya kekurangan pada penelitian ini dimana komunikasi interpersonal antara orangtua dengan remaja dapat diteliti secara lebih mendalam dengan membedakan antara komunikasi ayah dengan remaja maupun ibu dengan remaja. Selain itu, jumlah subjek yang digunakan dalam penelitian dapat diperbanyak sehingga memunculkan hasil yang lebih bervariasi.

Dari pemaparan semua data dan analisis statistik yang telah dilakukan, maka tujuan dari penelitian ini telah mampu terpenuhi yaitu untuk mengetahui hubungan komunikasi interpersonal antara orangtua-remaja dengan keterampilan sosial remaja. Komunikasi interpersonal antara orangtua dengan remaja yang efektif akan mendukung remaja dalam memiliki keterampilan sosial yang baik. Begitu juga sebaliknya, apabila komunikasi interpersonal yang dibangun antara orangtua dengan remaja tidak efektif, maka akan berdampak pada keterampilan sosial yang dimiliki remaja di lingkungan lain.

Berdasarkan penelitian yang telah dilakukan dan hasil analisis data penelitian yang didapat, maka peneliti menarik kesimpulan yaitu Terdapat hubungan yang signifikan antara komunikasi interpersonal orangtua-remaja dengan keterampilan sosial yang dimiliki remaja pada siswa SMA Dwijendra Denpasar. Komunikasi interpersonal antara orangtua-remaja memiliki hubungan yang positif dan searah dengan keterampilan sosial pada siswa SMA Dwijendra Denpasar, artinya semakin efektif komunikasi interpersonal yang dibangun antara orangtua dengan remaja maka akan semakin tinggi keterampilan sosial yang dimiliki remaja. Dari hasil penelitian juga didapat bahwa sebanyak 100\% remaja pada penelitian ini memiliki komunikasi interpersonal yang efektif dengan orangtua dan sebanyak $100 \%$ remaja pada penelitian ini memiliki keterampilan sosial dalam kategori sedang.

Berdasarkan kesimpulan yang telah didapat, peneliti dapat memberi saran bagi orangtua untuk membangun komunikasi yang baik dengan remaja, karena melalui komunikasi ini remaja dapat belajar banyak hal, terutama bagaimana bersosialisasi di lingkungan diluar keluarga. Melalui komunikasi pula orangtua dapat memberikan dukungan maupun nasehat yang dapat membantu remaja dalam menghadapi berbagai situasi dalam kehidupannya. Saran berikutnya dapat peneliti berikan pada pihak sekolah untuk menyediakan fasilitas pada siswa dalam mengembangkan keterampilan sosial melalui berbagai kegiatan, seperti kegiatan pramuka, kegiatan ekstrakurikuler, kelompok belajar, kegiatan perlombaan, serta kegiatan lainnya yang berupa kegiatan berkelompok sehingga siswa akan dapat sering berinteraksi. Sebagai sosok orangtua di lingkungan sekolah, guru diharapkan dapat memberi contoh berkomunikasi yang baik pada siswanya. Saran untuk remaja adalah untuk aktif berinteraksi dan berkomunikasi dengan orang di sekitar, baik orangtua maupun teman-teman, sehingga remaja dapat mengembangkan keterampilan sosial yang dimilikinya.

Bagi peneliti selanjutnya disarankan untuk dapat melakukan penelitian serupa dengan lebih memperdalam pada variabel komunikasi interpersonal, dimana tidak hanya meneliti komunikasi interpersonal antara orangtua dengan remaja, tetapi juga dibedakan antara komunikai ayah dengan remaja dan komunikasi ibu dengan remaja Peneliti selanjutnya juga dapat meneliti hal lain yang berhubungan dan dapat berkontribusi dalam keterampilan sosial yang dimiliki remaja selain komunikasi interpersonal yang dibangun dengan orangtua, seperti tipe kepribadian yang dimiliki remaja, keaktifan remaja dalam mengikuti kegiatan di sekolah, atau hubungan dengan teman sebaya.

\section{DAFTAR PUSTAKA}

Azwar, S. (2010). Reliabilitas dan validitas. Yogyakarta: Pustaka Pelajar.

Azwar, S. (2013). Metode penelitian (Edisi ke-1). Yogyakarta: Pustaka Pelajar.

Azwar, S. (2013). Penyusunan skala psikologi (Edisi ke-2). Yogyakarta: Pustaka Pelajar.

Budyatna, \& Ganiem. (2014). Teori komunikasi antarpribadi. Jakarta: Kencana.

Cangara, H. (2015). Pengantar ilmu komunikasi (Edisi Ke-2). Jakarta: Rajawali Pers.

Devito, J. A. (1997). Komunikasi antarmanusia (5th ed.). Jakarta: Professional Books.

Disiye dan Kodero. (2015). Influence of parent-adolescent communication on adolescent peer relations and gender implication.

Effendy, O.U. 2011. Ilmu komunikasi: Teori dan praktik. Bandung: PT. Remaja Rosdakarya.

Gimpel \& Merrel. (1998). Social skills of children and adolescents: Conceptualization, assessment, treatment. New York: Psychology Press.

Gunawan. (2013). Jenis pola komunikasi orangtua dengan anak perokok aktif di Desa Jembayan Kecamatan Loa Kulu Kabupaten Kutai Kartanegara. Jurnal Ilmu Komunikasi, 1 (3), 218-233.

Hargie, O. (2006). The handbook of communication skills (3rd ed). London: Routledge.

Hurlock. (2004). Psikologi perkembangan. Jakarta: Erlangga.

Kamumu. (2013). Hubungan antara komunikasi efektif orangtua dan anak dengan tingkat stres pada remaja siswa SMK Negeri 6 Yogyakarta.

Kartono, Kartini. (2013). Patologi sosial II: Kenakalan remaja. Jakarta: Rajawali Pers.

Leme, V. B. R., Del Prette, Z. A. P., \& Coimbra, S. (2015). Social skills, social support and well-being in adolescents of different family configurations.

Minarni. (2017). Hubungan Antara Komunikasi Interpersonal Orangtua dengan Perilaku Agresif pada Remaja Anggota Geng di Samarinda. 


\section{HUBUNGAN KOMUNIKASI INTERPERSONAL DAN KETERAMPILAN SOSIAL}

Mu'tadin, Z. (2006). Keterampilan

sosial

remaja. http://www.e-

psikologi.com/remaja/160802.htm. diakses tanggal 2 Februari 2016.

Normasari. (2013). Kepatuhan siswa kelas X dalam melaksanakan peraturan sekolah di SMK Muhammadiyah 3 Banjarmasin. Jurnal Pendidikan Kewarganegaraan, 3 (5), 320-326.

Olson, D. H. \& Defrain, J. (2003). Marriages and families: Intimacy, diversity, and strengths (4th ed.). New York: McGraw-Hill.

Papalia. (2009). Human development: Perkembangan manusia. Jakarta: Salemba Humanika.

Pratama. (2011). Pola hubungan komunikasi interpersonal antara orangtua dengan anak terhadap motivasi berprestasi pada anak (Studi pada SDN 01 Pagi Cipulir Kebayoran Lama Jakarta).

Ramadhani. (2013). Komunikasi interpersonal orangtua dan anak dalam membentuk perilaku positif pada murid SDIT Cordova Samarinda. Jurnal Ilmu Komunikasi, 1 (3), 112121.

Rice, F. P. \& Dolgin, K. G. (2002). The adolescent: Development, relationships, and culture (10th ed). Boston: Allyn and Bacon.

Rozali. (2016). Peran Pola Asuh Orangtua dalam Membentuk Keterampilan Sosial Remaja. Forum Ilmiah Volume 13 Nomor 2, Mei 2016

Santrock , W. S. (2003). Adolescence perkembangan remaja (6th ed.). Jakarta: Erlangga
Septiyani, Sukarti dan Indirawati. (2007). Hubungan antara persepsi remaja awal terhadap peran ayah dalam keluarga dengan keterampilan sosial pada remaja.

Shaffer, D. R. (2002). Developmental psychology: Childhood \& adolescence (6th ed). USA: Wadsworth/Thomson learning, Inc.

Suciati. (2015). Komunikasi interpersonal: Sebuah tinjauan psikologi dan perspektif islam. Yogyakarta: Buku Litera Yogyakarta.

Sugiyono. (2010). Metode Penelitian Pendidikan. Bandung : Alfabeta

Sugiyono. (2013). Metode penelitian kuantitatif, kualitatif, dan kombinasi (mixed methods). Bandung: Alfabeta.

Sugiyono. (2014). Statistika untuk penelitian. Bandung: Alfabeta.

Thakkar dan Sheth. (2014). Communication Patterns between Adolescents and their Parents.

Wijayanti. (2013). Proses komunikasi interpersonal ayah dan anak dalam menjaga hubungan. Tribunnews Bali. 14 Juni 2017. Meresahkan, 6 Remaja Keroyok dan Lakukan Penusukan di Jalan Pulau Buton Denpasar Ternyata. 12 Desember 2017. http://bali.tribunnews.com/2017/06/14/meresahkan-6remaja-keroyok-dan-lakukan-penusukan-di-jalan-pulaubuton-denpasar-ternyata

www.nusabali.com. 13 Oktober 2017. Otak Komplotan Begal Sadis Ternyata Pelajar SMA. 12 Desember 2017. http://www.nusabali.com/berita/20102/otak-komplotanbegal-sadis-ternyata-pelajar-sma

www.nusabali.com. 8 Desember 2017. Dua Remaja Putri Curi Helm Viral di Medsos. 12 Desember 2017. http://www.nusabali.com/berita/22097/dua-remaja-putricuri-helm-viral-di-medsos 


\section{LAMPIRAN}

Tabel 1

Hasil Uji Normalitas Variabel Penelitian

\begin{tabular}{ccc}
\hline Variabel & Kolmogorov-Smirnov & Asymp. Sig. (2-tailed) \\
\hline $\begin{array}{c}\text { Kom unikasi Interpersonal } \\
\text { antara Orangtua-Remaja }\end{array}$ & 0,578 & 0,892 \\
\hline Keterampilan Sosial & 0,483 & 0,974 \\
\hline
\end{tabular}

Tabel 2

Hasil Uji Linearitas Variabel Penelitian

\begin{tabular}{lllrr}
\hline & & F & Signifikansi \\
\hline Keterampilan sosial * & Between & (Combined) & 3.883 & .000 \\
Komunikasi interpersonal & Group & Linearity & 112.537 & .000 \\
& & $\begin{array}{l}\text { Deviation from } \\
\text { Linearity }\end{array}$ & 1.413 & .098 \\
\hline
\end{tabular}

Tabel 3

Hasil Uji Korelasi Pearson Product Moment

\begin{tabular}{llll}
\hline Pearson Correlation & $\begin{array}{l}\text { Komunikasi } \\
\text { Interpersonal }\end{array}$ & $\begin{array}{l}\text { Keterampilan } \\
\text { Sosial }\end{array}$ & $\begin{array}{l}\text { Sig. } \\
\text { tailed) }\end{array}$ \\
\hline $\begin{array}{l}\text { Komunkiasi } \\
\text { Interpersonal }\end{array}$ & 1 & 0,681 & 0,000 \\
\hline Keterampilan Sosial & 0,681 & 1 & 0,000 \\
\hline
\end{tabular}

Tabel 4

Kategorisasi Komunikasi Interpersonal Orangtua-Remaja

\begin{tabular}{cccc}
\hline Rentang Nilai & Kategori & Jumlah & Persentase \\
\hline Kurang Efektif & $\mathrm{X}<82$ & 0 & $0 \%$ \\
\hline Efektif & $82 \leq \mathrm{X}<123$ & 114 & $100 \%$ \\
\hline Sangat Efektif & $123 \leq \mathrm{X}$ & 0 & $0 \%$ \\
\hline
\end{tabular}

Tabel 5

Kategorisasi Keterampilan Sosial

\begin{tabular}{cccc}
\hline Rentang Nilai & Kategori & Jumlah & Persentase \\
\hline Rendah & $\mathrm{X}<116$ & 0 & $0 \%$ \\
\hline Sedang & $116 \leq \mathrm{X}<174$ & 114 & $100 \%$ \\
\hline Tinggi & $174 \leq \mathrm{X}$ & 0 & $0 \%$ \\
\hline
\end{tabular}

